\title{
Extraction Socket Preservation Using Growth Factors and Stem Cells: a Systematic Review
}

\author{
Mindaugas Pranskunas', Pablo Galindo-Moreno², Miguel Padial-Molina² \\ ${ }^{1}$ Department of Oral and Maxillofacial Surgery, Faculty of Odontology, Medical Academy, Lithuanian University of Health \\ Sciences, Kaunas, Lithuania. \\ ${ }^{2}$ Department of Oral Surgery and Implant Dentistry. School of Dentistry, University of Granada, Granada, Spain.
}

\author{
Corresponding Author: \\ Mindaugas Pranskunas \\ P. Vileisio 3A-36, LT-10308, Vilnius \\ Lithuania \\ Phone: +37065941955 \\ E-mail: mindaugaspranskunas@hotmail.1t
}

\begin{abstract}
Objectives: To evaluate the reported literature on the use of stem cells or growth factors for post extraction treatment of the alveolar bone.

Material and Methods: A NCBI PubMed and PubMed Central databases search was conducted between September 2010 and August 2018, to identify animal or clinical studies reporting the clinical, radiographical and/or histological outcomes of socket preservation techniques after applying mesenchymal stem cells or growth factors. Only studies published in English language in the last 10 years were included in the study.

Results: Eleven studies were identified fulfilling the inclusion criteria. They evaluate a total of 386 post extraction sockets. The main tested materials identified in the current review were bone morphogenetic protein- 2 - 3 studies and mesenchymal stem cells - 3 studies. Other comparators were bone morphogenetic protein-9, platelet-derived growth factor-BB homodimers and bone marrow. Overall evaluation indicate positive results for all test groups showing differences in final socket width between 0.64 and $1.28 \mathrm{~mm}$ favouring the test groups. Histologically, no particular differences are detected between test and control groups. Most of the studies present low risk of bias.

Conclusions: In general, the use of mesenchymal stem cells or bioactive osteogenic molecules favours bone regeneration after tooth extraction, as evaluated clinically, radiographically and histologically. However, specific differences that support particular recommendations are still unclear in light of the current published evidence. Future studies should include the standardization of the mesenchymal stem cells selection and purification as well as dosage and delivery methods of bioactive molecules.
\end{abstract}

Keywords: alveolar bone atrophy; alveolar bone grafting; bone remodeling; mesenchymal stem cells; stem cell transplantation; transforming growth factors.

\author{
Accepted for publication: 5 September 2019 \\ To cite this article: \\ Pranskunas M, Galindo-Moreno P, Padial-Molina M. \\ Extraction Socket Preservation Using Growth Factors and Stem Cells: a Systematic Review \\ J Oral Maxillofac Res 2019;10(3):e7 \\ URL: http://www.ejomr.org/JOMR/archives/2019/3/e7/v10n3e7.pdf \\ doi: $\underline{10.5037 / \text { jomr.2019.10307 }}$
}




\section{INTRODUCTION}

Tooth extraction is possibly the most commonly performed surgical procedure in dentistry. Following the extraction of teeth, the alveolar bone losses its supportive function. As a consequence, it is progressively resorbed [1]. Thus, in many cases, remaining bone volume may not be sufficient to properly support the placement of a dental implant in the correct three-dimensional position. Because of this, in recent years, filling of the socket with different biomaterials has been promoted [2]. Also, in cases when alveolar bone is lost, its reconstruction after the extraction of the tooth has been investigated. Regardless of the method and the biomaterial used, some level of volume loss should be expected [3] . Thus, better materials and techniques should be investigated.

Bone regeneration, as previously reviewed [4], "requires the migration of specific cells to the healing area to proliferate and provide the biological substrate for the new tissue to grow". Cell migration, proliferation and differentiation is regulated by a number of soluble factors in coordination with extracellular signals, three-dimensional support and scaffolds and with the correct blood supply. A number of scaffolds have been proposed in the literature. However, the bioactive molecules and cells with differentiation potential are still more un-used [4].

Stem cells have the capacity to self-renew and, under the adequate stimuli, to differentiate into multiple celltypes, depending on their potential. In the particular case of mesenchymal stem cells (MSC), they have the potential to differentiate into adipo-, chondro- and osteo-genic tissues [5]. Thus, they have been studied for a great number of regenerative cell-based therapies. This includes regeneration of maxillofacial bone. MSC can be obtained from a number of different adult tissues, including many in the oral cavity [6], mainly the bone marrow, dental pulp and periodontal ligament [7-9]. MSC from the oral cavity have demonstrated all the characteristics to consider a cell population as a MSC: growth kinetics, cumulative population doubling, total number of passages, clonogenicity, expression of surface markers and stemness genes and multilineage differentiation potential [ 6 ]. Because of this, they have gained interest from the scientific community to be used locally in maxillofacial defects. Although Sonoyama et al. [10] discussed the different differentiation potential of MSC from different origins, it must be noted that most properties are similar among MSC [11].

It should also be noted that before MSCs were proposed to be used for bone regeneration, growth factors and other bioactive molecules had been suggested [12], including platelet derived growth factor (PDGF), fibroblast growth factor, insulingrowth factor and bone morphogenetic proteins (BMPs) [4]. Moreover, around the use of bioactive molecules, a plethora of techniques have been developed in order to reduce the dosage of the drug while improving its timely delivery $[13,14]$.

Thus, it is the aim of the current review to evaluate the use of mesenchymal stem cells and bioactive molecules for bone regeneration after tooth extraction.

\section{MATERIAL AND METHODS Protocol and registration}

This systematic literature reviews adheres to the PRISMA Statement [15].

The review protocol was registered before any search was conducted in an international prospective register of systematic reviews (PROSPERO) in which the methodology and inclusion and exclusion criteria were specified and documented in advance. The protocol can be accessed at:

https://www.crd.york.ac.uk/PROSPERO/display record.php?RecordID $=136092$ with the registration number: CRD42019136092.

\section{Focus question}

The following focus question was developed according to the problem, intervention, comparison, and outcome (PICO) design (Table 1).

What biomaterials in combination with stem cells and growth factors are used for socket preservation after the tooth extraction and which of those show the best results regarding alveolar dimensional changes and quality of newly formed bone?

\section{Types of publications}

Studies on humans or animals that had been published in the English language were included in the review. Other type of reports, such as abstracts, $\mathrm{PhD}$ theses, literature reviews, editorials and letters were excluded. Publication time was established between April 7, 2010 and January 27, 2018.

\section{Types of studies}

The review included clinical, comparative, prospective, cohort and case series studies on various extraction socket preservation procedures using 
Table 1. The focus question development according to the PICOS study design

\begin{tabular}{l|l}
\hline \multicolumn{1}{c|}{ Component } & \multicolumn{1}{c}{ Description } \\
\hline Problem (P) & Bone resorption after tooth extraction \\
\hline Intervention (I) & Filling alveolar socket with regenerative biomaterial \\
\hline Comparison (C) & Comparison between efficiency of different biomaterials \\
\hline Outcome (O) & Different dimensional changes of alveolar bone \\
\hline Study design (S) & Random controlled trial \\
\hline Focus question & $\begin{array}{l}\text { What biomaterials in combination with stem cells and growth factors are used for socket preservation after the tooth } \\
\text { extraction and which of those show the best results regarding alveolar dimensional changes and quality of newly formed } \\
\text { bone? }\end{array}$ \\
\hline
\end{tabular}

growth factors and stem cells. Case reports were excluded.

\section{Information sources}

The search strategy was introduced into electronic databases (NCBI PMC and PubMed) and supplemented by hand searches in dental implant related journals, particularly "Clinical Oral Implants Research", "International Journal of Oral and Maxillofacial Surgery", "European Journal of Oral Implantology", "Journal of Clinical Periodontology", "Journal of Oral and Maxillofacial Implants", "Journal of Periodontology", "Journal of Oral and Maxillofacial Surgery", and "The International Journal of Periodontics and Restorative Dentistry". In addition, the references of the included relevant studies were screened to find potential relevant publications not included in the previous search to improve the sensitivity.

\section{Search}

The databases were explored through advanced searches. The following search inquiries were used: "extraction socket" OR "extraction socket" AND "growth factors" OR "extraction socket" AND "stem cells" OR "extraction socket" AND "mesenchymal stem cells" OR "alveolar ridge preservation" OR "alveolar ridge preservation" AND "stem cells" OR "alveolar ridge preservation" AND "mesenchymal stem cells" OR "socket preservation" OR "socket preservation" AND "stem cells" OR "socket preservation" AND "'mesenchymal stem cells". These keywords were selected in order to collect as much relevant references as possible.

\section{Selection of studies}

Two reviewers (MP and MP-M) evaluated the resulting articles according to clear criteria for inclusion and exclusion. The reviewers made decisions and set differences through discussion. If consensus about inclusion or exclusion could not be reached, a third party (an experienced senior reviewer, PG-M) was consulted and his decision adopted.

\section{Inclusion and exclusion criteria}

Studies were included if they fulfil the following criteria as follows:

- Investigated changes of bone dimensions or quality after preservation, regeneration or tissue formation using stem cells and/or growth factors after tooth extraction;

- Human or animal studies and clinical trials, comparative studies, prospective studies, feasibility trials, cohort studies and case series studies;

- At least 1 month of follow-up after the extraction and following procedure;

- If before careful reading the study could not be excluded.

If articles presented any of the following, they were excluded from the current review:

- Studies that evaluated bone lateral augmentation, sinus lifts or other type of bone grafting or regeneration;

- Studies where the effect of stem cells and growth factors influence in post extraction socket regeneration could not be analysed from the data;

- Studies that presented unclear data;

- Studies older than 10 years;

- Articles written not in English language.

\section{Sequential search strategy}

After the initial literature search, case reports, review articles and other irrelevant publications were eliminated by reading the titles of the studies. Then, abstracts of the pre-selected studies were evaluated to further exclude irrelevant publications. The final stage of article selection involved reading the full texts [1643], and based on the inclusion and exclusion criteria 
defined above, confirm each study's eligibility.

\section{Data extraction}

The data from different studies were registered from studies according to the interests of the current review, as listed below.

\section{Data items}

Data from the included articles were collected and organised in in columns with the following information: author and year, sample size for this outcome/measure, defect location/defect type, measuring method (clinical, histological, radiography), test groups, surgical protocol, results, and outcome.

\section{Assessment of methodological quality}

As part of the data extraction process, two review authors assessed the risk of bias of the included studies. To do so, the recommended approach for assessing risk of bias in studies included in Cochrane reviews was used [44].

\section{Synthesis of results}

As mentioned, tables were prepared with the fields included as data items.

\section{Statistical analysis}

Due to the high heterogeneity between the studies, no meta-analysis could be performed. Thus, only a descriptive evaluation is presented.

\section{RESULTS \\ Study selection}

Article review, selection and data extraction were conducted as shown in the PRISMA flow diagram (Figure 1). As it can be observed, the initial search located a total of 2342 articles. Of those, 408 were identified as potentially relevant articles by the screening of the article titles. The abstracts were read and from there, 39 publications were selected for possible inclusion. Finally, these 39 publications were evaluated in full-text. After applying the inclusion and exclusion criteria, 11 articles fulfil the predefined criteria and were, therefore, incorporated in the systematic review.

There are no reasons for exclusion. Excluded full text articles should be included into references list. If it is big number, so show most often reasons and numbers how much for each reason excluded.

Eight of them are clinical trials (extraction sockets number: 295), two animal studies (extraction sockets number: 44), one prospective pilot clinical study (extraction sockets number: 47). Total extraction sockets number: 386.

\section{Study characteristics}

The included studies compared ridge dimension changes and bone formation considering the number of extraction sockets and clinical, radiological or histological parameters.

\section{Influence of MSC and growth factors for extraction socket preservation Clinical/radiographical measurements}

Changes of post extraction sockets dimensions were metered in six studies. Three of them for sockets preservation as test group used BMP-2 [45-47] and collagen sponge [46], demineralized bone [45] or hydroxyapatite [47] as matrix. One study used MSC [48] and collagen membrane as a matrix, another one used BMP-9 [49] and collagen membrane, and in one study sockets were filled with bone marrow without any matrix [50]. The difference of socket width between test and control groups varies from 0.64 to $1.279 \mathrm{~mm}$. Despite the heterogeneity of studies, all test groups showed statistically significant better results comparing to control groups or unassisted healing (Table 1).

\section{Histological measurements}

The percentage of new bone or connective tissue that had invaded the former space of the root was examined in five articles [51-55]. In these studies platelet-derived growth factor-BB homodimers (PDGF-BB) [51], BMP-2 [52], bovine bone + poly (L-lactide-coE-caprolactone), PDGF-BB [53], and MSC [55] were used as test groups. Collagen sponge (Collaplug $^{\circledR}$; Zimmer DentaI Inc., Carlsbad, CA, USA) $[51,52]\left(\right.$ Bio-Oss ${ }^{\circledR}$ Collagen; Geistlich Pharma AG, Wolhusen, Switzerland) [54] and gelatine sponge $\left(\right.$ Gelfoam $^{\circledR}$; Pfizer Inc, New York, USA) [55], were used as comparator. New bone formation in test groups varies between 28 and 49.6\%. Connective tissue percentage in test groups varies between 19.6 and $50.4 \%$. Otherwise than in clinical/radiological measurements two of these five studies showed no significant difference between test and control groups. 


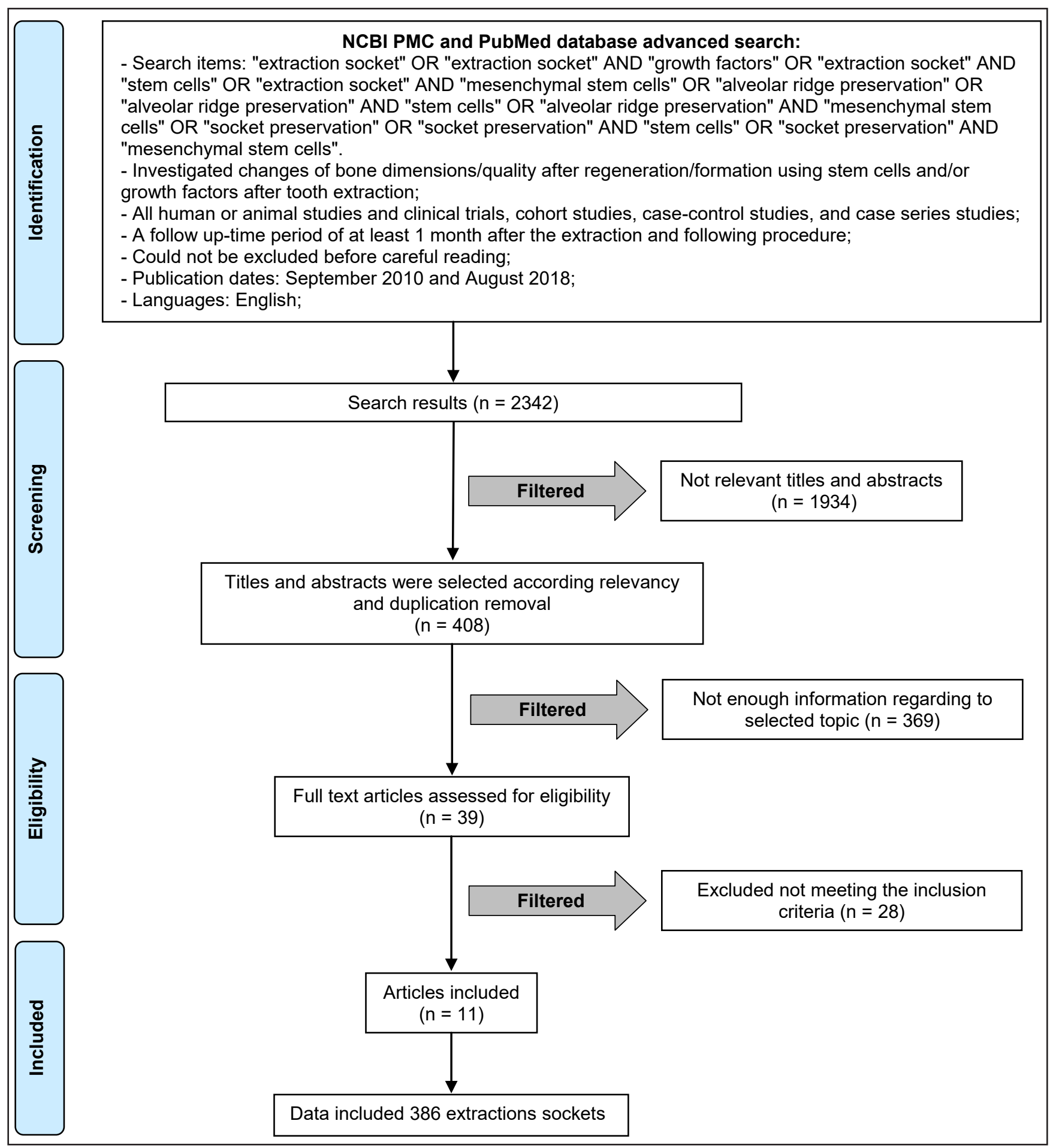

Figure 1. PRISMA flow diagram.

Moreover, one article demonstrates that usage of recombinant human PDGF-BB produced less residual bone graft material, indicating more rapid turnover of bone graft during early healing (8 weeks) [51] (Table 2).

\section{Quality assessment}

The majority of the included studies have an unknown risk of bias for one or more key domains

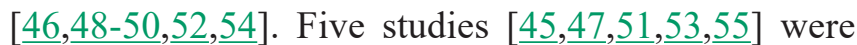
classified as low risk of bias for all key domains (Table 3).

\section{DISCUSSION}

The current review has found a number of studies analysing the use of MSC and/or bioactive molecules for socket preservation/regeneration. 
Table 2. Characteristics of studies determine alveolar ridge dimensions (quality, quantity) changes after different ridge preservation methods

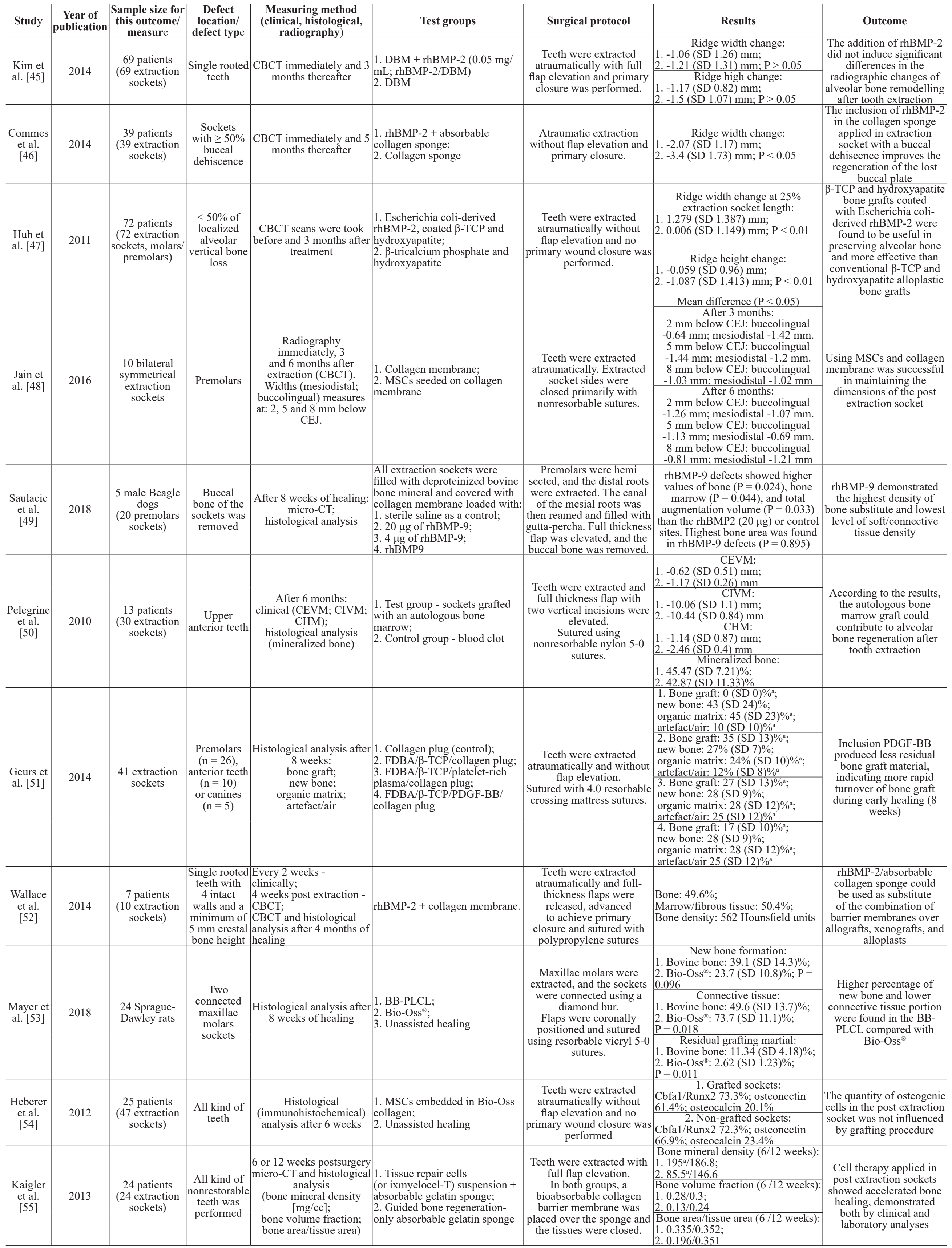

andicates statistical significance.

$\mathrm{CBCT}=$ cone-beam computed tomography $\mathrm{CT}=$ computed tomography $\mathrm{CEJ}=$ cementoenamel junction; $\mathrm{DBM}=$ demineralized bone matrix $; \mathrm{CEVM}=$ clinical external vertical measurement $\mathrm{CIVM}=$ clinical internal vertical measurement; $\mathrm{CHM}=$ clinical horizontal measurement; Cbfa1/Runx2 = core-binding factor a $1 /$ runx-related protein $2 ; \mathrm{MSC}=$ mesenchymal stem cells; $\beta$-TCP $=\beta$-tricalcium phosphate; PDGF-BB = platelet-derived growth factor-BB homodimers. 
Table 3. Bias summary

\begin{tabular}{l|c|c|c|c|c|c}
\hline \multicolumn{1}{c|}{ Study } & $\begin{array}{c}\text { Random } \\
\text { sequence } \\
\text { generation }\end{array}$ & $\begin{array}{c}\text { Allocation } \\
\text { concealment }\end{array}$ & $\begin{array}{c}\text { Blinding of } \\
\text { outcome } \\
\text { assessment }\end{array}$ & $\begin{array}{c}\text { Incomplete } \\
\text { outcome } \\
\text { data }\end{array}$ & $\begin{array}{c}\text { Selective } \\
\text { reporting }\end{array}$ & $\begin{array}{c}\text { Other } \\
\text { sources of } \\
\text { bias }\end{array}$ \\
\hline Kim et al. [45] & + & + & + & + & + & + \\
\hline Coomes et al. [46] & $?$ & $?$ & + & + & + & + \\
\hline Huh et al. [47] & + & + & + & + & + & + \\
\hline Jain et al. [48] & $?$ & + & + & + & + & + \\
\hline Saulacic et al. [49] & + & + & + & + & + & + \\
\hline Pelegrine et al. [50] & $?$ & $?$ & + & + & + & + \\
\hline Geurs et al. [51] & + & + & + & + & + & + \\
\hline Wallace et al. [52] & $?$ & $?$ & + & + & + & + \\
\hline Mayer et al. [53] & + & + & + & + & + & + \\
\hline Heberer et al. [54] & $?$ & + & + & + & + \\
\hline Kaigler et al. [55] & + & + & + & + & + \\
\hline
\end{tabular}

$+=$ low risk; $?=$ unclear risk; $-=$ high risk.

Most of them indicate, as it could be arguably expected, because of publication bias, a noninferiority of the test group under study, regardless of the specific agent and the comparator control group. Post extraction sockets are usually selfcontained and small defects. Thus, the potential advantages of additional products, beside those for maintaining the space (traditional particulated bone grafts) and excluding soft tissue invasion (guided tissue regeneration membranes), might be limited. This does not necessarily mean that they are not useful though. On the contrary, it reflects a lack of standardization in the clinical application of these methods. As previously reviewed [4], the application of MSCs for bone regeneration within the oral cavity varies tremendously in the observation period, specific therapeutic application, carrier, origin of the MSCs and method of purification of such cells. Because of this diversity, comparison among studies is complicated. Noteworthy, the current study found only three studies using MSC for bone regeneration after tooth extraction. In all three cases, MSC were obtained from the iliac crest. However, neither the carrier nor the processing method was standard in all cases: one used an automatic subculturing and purification process for 14 days and implanted the cells through a collagen sponge [55], other manually subcultured the cells during 10 days and implanted them in a collagen membrane [48] and the other extracted the bone marrow and applied it directly with no subculture nor purification [50]. Because of this, in addition to other differences in the evaluation method, specific differences in results might be explained. In any case, in all three cases, positive outcomes were reported.

On the other hand, bioactive molecules that regulate the process of MSC differentiation also report positive results in all cases under review in the current manuscript. The most analysed growth factor is a member of the transforming growth factor- $\beta$ superfamily, the bone morphogenetic proteins, particularly BMP-2 [14]. BMPs can induce angiogenesis, synthesis of the extracellular matrix, chondrogenesis and osteogenesis. BMP-2 is probably the most active inductor of bone formation, being able to compensate for the absence of other members of the family [56]. The natural activity of BMP-2 is initiated after bone resorption, when the resorptive activity of osteoclasts releases the BMP from the matrix [14]. However, the reported use of BMP-2 for bone regeneration also lacks from standardization among studies. One of the main issues identified in previous and current reports is the dosage of the recombinant protein and the delivery method. Either absorbable collagen sponges $[46,52]$ or mineralized grafts $[45, \underline{47,49}]$ have been identified as carriers in the current review. In both cases, the addition of the protein seems to induce better outcomes. Similar results have been indicated in previous reviews, in which particular doses were recommended (1.5 $\mathrm{mg} / \mathrm{ml}$ ) [20]. In more recent years, another step has been taken into the use of this kind of active molecules. A protein is usually rapidly deactivated by denaturalization. Also, proper bioactivity requires the protein to be active at a specific time. Thus, protecting the activity of the protein by means of poly-lacticco-glycolic acid nanoparticles has been proposed. Moreover, a controlled release may also be beneficial for the success of these techniques [13]. However, so far, these techniques have not yet been applied clinically.

Other bioactive molecules may also provide positive results, including but not limited to those identified 
in the current review, such as PDGF-BB. PDGF activity had been initially analysed for periodontal tissue regeneration [57] for its capacity to induce not only cell differentiation but also, and mainly, new vascular development. Thus, its application for bone regeneration might also be useful. The current review has not found sufficient evidence to support clear indications about this molecule, but in turn, negative results from one of the studies in which it was evaluated [51].

In summary, the current review presented an overview of different studies showing the outcomes after using either MSC or regulatory molecules for bone regeneration in the context of after-tooth-extraction therapies. In view of the current review and according to previous reports [21], it must be concluded that beside the positive reported outcomes, no clear conclusion nor recommendation on the use of these techniques can be made because of the different methods applied in the studies under analysis.

\section{CONCLUSIONS}

Stem cells and growth factors usage for alveolar ridge preservation are promising for future daily clinical practice. Today, these methods need to be standardized and based on more scientific data. Recommendations for future studies should include the standardization of the mesenchymal stem cells selection and purification as well as a specific effort into conducting comparable studies in the current topic.

\section{ACKNOWLEDGMENTS AND DISCLOSURE STATEMENTS}

The authors declare no conflict of interest related to any of the products mentioned in the current study. PG-M and MP-M are partially supported by Research Groups CTS-1028 - "Oral Biology and Regeneration" (Junta de Andalucia, Spain).

\section{REFERENCES}

1. Amler MR, Johnson PL, Salman I. Histological and histochemical investigation of human alveolar socket healing in undisturbed extraction wounds. J Am Dent Assoc. 1960 Jul;61:32-44. [Medline: 13793201] [doi: 10.14219/jada.archive.1960.0152]

2. Cardaropoli G, Araújo M, Hayacibara R, Sukekava F, Lindhe J. Healing of extraction sockets and surgically produced augmented and non-augmented - defects in the alveolar ridge. An experimental study in the dog. J Clin Periodontol. 2005 May;32(5):435-40. [Medline: 15842256] [doi: 10.1111/j.1600-051X.2005.00692.x]

3. Avila-Ortiz G, Elangovan S, Kramer KW, Blanchette D, Dawson DV. Effect of alveolar ridge preservation after tooth extraction: a systematic review and meta-analysis. J Dent Res. 2014 Oct;93(10):950-8. [Medline: 24966231] [PMC free article: 4293706] [doi: 10.1177/0022034514541127]

4. Padial-Molina M, O'Valle F, Lanis A, Mesa F, Dohan Ehrenfest DM, Wang HL, Galindo-Moreno P. Clinical Application of Mesenchymal Stem Cells and Novel Supportive Therapies for Oral Bone Regeneration. Biomed Res Int. 2015;2015:341327. [Medline: 26064899] [PMC free article: 4443638] [doi: 10.1155/2015/341327]

5. Dominici M, Le Blanc K, Mueller I, Slaper-Cortenbach I, Marini F, Krause D, Deans R, Keating A, Prockop Dj, Horwitz E. Minimal criteria for defining multipotent mesenchymal stromal cells. The International Society for Cellular Therapy position statement. Cytotherapy. 2006;8(4):315-7. [Medline: 16923606] [doi: 10.1080/14653240600855905]

6. Padial-Molina M, de Buitrago JG, Sainz-Urruela R, Abril-Garcia D, Anderson P, O’Valle F, Galindo-Moreno P. Expression of Musashi-1 During Osteogenic Differentiation of Oral MSC: An In Vitro Study. Int J Mol Sci. 2019 May 2;20(9). pii: E2171. [Medline: 31052494] [PMC free article: 6539002] [doi: 10.3390/ijms20092171]

7. Gronthos S, Mankani M, Brahim J, Robey PG, Shi S. Postnatal human dental pulp stem cells (DPSCs) in vitro and in vivo. Proc Natl Acad Sci U S A. 2000 Dec 5;97(25):13625-30. [Medline: 11087820] [PMC free article: 17626] [doi: 10.1073/pnas.240309797]

8. Miura M, Gronthos S, Zhao M, Lu B, Fisher LW, Robey PG, Shi S. SHED: stem cells from human exfoliated deciduous teeth. Proc Natl Acad Sci U S A. 2003 May 13;100(10):5807-12. [Medline: 12716973] [PMC free article: 156282] [doi: 10.1073/pnas.0937635100]

9. Seo BM, Miura M, Gronthos S, Bartold PM, Batouli S, Brahim J, Young M, Robey PG, Wang CY, Shi S. Investigation of multipotent postnatal stem cells from human periodontal ligament. Lancet. 2004 Jul 10-16;364(9429):149-55. [Medline: 15246727] [doi: 10.1016/S0140-6736(04)16627-0]

10. Sonoyama W, Liu Y, Fang D, Yamaza T, Seo BM, Zhang C, Liu H, Gronthos S, Wang CY, Wang S, Shi S. Mesenchymal stem cell-mediated functional tooth regeneration in swine. PLoS One. 2006 Dec 20;1:e79. [Medline: 17183711] [PMC free article: 1762318] [doi: 10.1371/journal.pone.0000079]

11. Pettersson LF, Kingham PJ, Wiberg M, Kelk P. In Vitro Osteogenic Differentiation of Human Mesenchymal Stem Cells from Jawbone Compared with Dental Tissue. Tissue Eng Regen Med. 2017 Aug 28;14(6):763-774. [Medline: 30603526] [PMC free article: 6171664] [doi: 10.1007/s13770-017-0071-0] 
12. Sood S, Gupta S, Mahendra A. Gene therapy with growth factors for periodontal tissue engineering--a review. Med Oral Patol Oral Cir Bucal. 2012 Mar 1;17(2):e301-10. [Medline: 22143705] [PMC free article: 3448311] [doi: 10.4317/medoral.17472]

13. Ortega-Oller I, Del Castillo-Santaella T, Padial-Molina M, Galindo-Moreno P, Jódar-Reyes AB, Peula-García JM. Dual delivery nanosystem for biomolecules. Formulation, characterization, and in vitro release. Colloids Surf B Biointerfaces. 2017 Nov 1;159:586-595. [Medline: 28854415] [doi: 10.1016/j.colsurfb.2017.08.027]

14. Ortega-Oller I, Padial-Molina M, Galindo-Moreno P, O’Valle F, Jódar-Reyes AB, Peula-García JM. Bone Regeneration from PLGA Micro-Nanoparticles. Biomed Res Int. 2015;2015:415289. [Medline: 26509156] [PMC free article: 4609778] [doi: 10.1155/2015/415289]

15. Liberati A, Altman DG, Tetzlaff J, Mulrow C, Gøtzsche PC, Ioannidis JP, Clarke M, Devereaux PJ, Kleijnen J, Moher D. The PRISMA statement for reporting systematic reviews and meta-analyses of studies that evaluate health care interventions: explanation and elaboration. J Clin Epidemiol. 2009 Oct;62(10):e1-34. [Medline: 19631507] [doi: 10.1016/j.jclinepi.2009.06.006]

16. Al Yafi F, Alchawaf B, Nelson K. What is the Optimum for Alveolar Ridge Preservation? Dent Clin North Am. 2019 Jul;63(3):399-418. [Medline: 31097134] [doi: 10.1016/j.cden.2019.02.007]

17. Li Y, Nan X, Zhong TY, Li T, Li A. Treatment of Periodontal Bone Defects with Stem Cells from Inflammatory Dental Pulp Tissues in Miniature Swine. Tissue Eng Regen Med. 2019 Mar 11;16(2):191-200. [Medline: 30989045] [doi: $10.1007 / \mathrm{s} 13770-018-00175-7]$

18. Boeckel DG, Sesterheim P, Peres TR, Augustin AH, Wartchow KM, Machado DC, Fritscher GG, Teixeira ER. Adipogenic Mesenchymal Stem Cells and Hyaluronic Acid as a Cellular Compound for Bone Tissue Engineering. J Craniofac Surg. 2019 May/Jun;30(3):777-783. [Medline: 30865107] [doi: 10.1097/SCS.0000000000005392]

19. Fujioka-Kobayashi M, Schaller B, Saulacic N, Pippenger BE, Zhang Y, Miron RJ. Absorbable collagen sponges loaded with recombinant bone morphogenetic protein 9 induces greater osteoblast differentiation when compared to bone morphogenetic protein 2. Clin Exp Dent Res. 2017 Feb 9;3(1):32-40. [Medline: 29744176] [PMC free article: 5839213] [doi: $10.1002 / \mathrm{cre} 2.55]$

20. Moslemi N, Khoshkam V, Rafiei SC, Bahrami N, Aslroosta H. Outcomes of Alveolar Ridge Preservation With Recombinant Human Bone Morphogenetic Protein-2: A Systematic Review. Implant Dent. 2018 Jun;27(3):351-362. [Medline: 29394177] [doi: 10.1097/ID.0000000000000722]

21. Willenbacher M, Al-Nawas B, Berres M, Kämmerer PW, Schiegnitz E. The Effects of Alveolar Ridge Preservation: A Meta-Analysis. Clin Implant Dent Relat Res. 2016 Dec;18(6):1248-1268. [Medline: 26132885] [doi: $10.1111 / \mathrm{cid} .12364]$

22. Fickl S, Zuhr O, Wachtel H, Stappert CF, Stein JM, Hürzeler MB. Dimensional changes of the alveolar ridge contour after different socket preservation techniques. J Clin Periodontol. 2008 Oct;35(10):906-13. [Medline: 18713258] [doi: 10.1111/j.1600-051X.2008.01305.x]

23. Cicciù M, Herford AS, Cicciù D, Tandon R, Maiorana C. Recombinant human bone morphogenetic protein-2 promote and stabilize hard and soft tissue healing for large mandibular new bone reconstruction defects. J Craniofac Surg. 2014 May;25(3):860-2. [Medline: 24820713] [doi: 10.1097/SCS.0000000000000830]

24. De Sarkar A, Singhvi N, Shetty JN, Ramakrishna T, Shetye O, Islam M, Keerthy H. The Local Effect of Alendronate with Intra-alveolar Collagen Sponges on Post Extraction Alveolar ridge Resorption: A Clinical Trial. J Maxillofac Oral Surg. 2015 Jun;14(2):344-56. [Medline: 26028857] [PMC free article: 4444695] [doi: 10.1007/s12663-014-0633-9]

25. Herford AS, Tandon R, Stevens TW, Stoffella E, Cicciu M. Immediate distraction osteogenesis: the sandwich technique in combination with rhBMP-2 for anterior maxillary and mandibular defects. J Craniofac Surg. 2013 Jul;24(4):1383-7. [Medline: 23851812] [doi: 10.1097/SCS.0b013e318292c2ce]

26. Behnia H, Khojasteh A, Soleimani M, Tehranchi A, Atashi A. Repair of alveolar cleft defect with mesenchymal stem cells and platelet derived growth factors: a preliminary report. J Craniomaxillofac Surg. 2012 Jan;40(1):2-7. [Medline: 21420310] [doi: 10.1016/j.jcms.2011.02.003]

27. Draenert FG, Nonnenmacher AL, Kämmerer PW, Goldschmitt J, Wagner W. BMP-2 and bFGF release and in vitro effect on human osteoblasts after adsorption to bone grafts and biomaterials. Clin Oral Implants Res. 2013 Jul;24(7):750-7. [Medline: 22524399] [doi: 10.1111/j.1600-0501.2012.02481.x]

28. Miron RJ, Saulacic N, Buser D, Iizuka T, Sculean A. Osteoblast proliferation and differentiation on a barrier membrane in combination with BMP2 and TGF $\beta 1$. Clin Oral Investig. 2013 Apr;17(3):981-8. [Medline: 22669486] [doi: 10.1007/s00784-012-0764-7]

29. Misch CM. The use of recombinant human bone morphogenetic protein-2 for the repair of extraction socket defects: a technical modification and case series report. Int J Oral Maxillofac Implants. 2010 Nov-Dec;25(6):1246-52. [Medline: 21197504]

30. Wallace S. Histomorphometric and 3D Cone-Beam Computerized Tomographic Evaluation of Socket Preservation in Molar Extraction Sites Using Human Particulate Mineralized Cancellous Allograft Bone With a Porcine Collagen Xenograft Barrier: A Case Series. J Oral Implantol. 2015 Jun;41(3):291-7. [Medline: 24987870] [doi: 10.1563/aaid-joi-D-14-00078] 
31. Begam H, Nandi SK, Kundu B, Chanda A. Strategies for delivering bone morphogenetic protein for bone healing. Mater Sci Eng C Mater Biol Appl. 2017 Jan 1;70(Pt 1):856-869. [Medline: 27770964] [doi: 10.1016/j.msec.2016.09.074]

32. Howell TH, Fiorellini J, Jones A, Alder M, Nummikoski P, Lazaro M, Lilly L, Cochran D. A feasibility study evaluating rhBMP-2/absorbable collagen sponge device for local alveolar ridge preservation or augmentation. Int J Periodontics Restorative Dent. 1997 Apr;17(2):124-39. [Medline: 9497707]

33. Levin BP, Tawil P. Posterior tooth replacement with dental implants in sites augmented with rhBMP-2 at time of extraction-a case series. Compend Contin Educ Dent. 2012 Feb;33(2):104-8, 110; quiz 111-2. [Medline: 22545428]

34. Hong JY, Lee JS, Pang EK, Jung UW, Choi SH, Kim CK. Impact of different synthetic bone fillers on healing of extraction sockets: an experimental study in dogs. Clin Oral Implants Res. 2014 Feb;25(2):e30-7. [Medline: 22970654] doi: 10.1111/clr.12041]

35. Fujioka-Kobayashi M, Sawada K, Kobayashi E, Schaller B, Zhang Y, Miron RJ. Recombinant Human Bone Morphogenetic Protein 9 (rhBMP9) Induced Osteoblastic Behavior on a Collagen Membrane Compared With rhBMP2. J Periodontol. 2016 Jun;87(6):e101-7. [Medline: 26751345] [doi: 10.1902/jop.2016.150561]

36. Spagnoli D, Choi C. Extraction socket grafting and buccal wall regeneration with recombinant human bone morphogenetic protein-2 and acellular collagen sponge. Atlas Oral Maxillofac Surg Clin North Am. 2013 Sep;21(2):175-83. [Medline: 23981493] [doi: 10.1016/j.cxom.2013.05.003]

37. Zhang Y, Yang S, Zhou W, Fu H, Qian L, Miron RJ. Addition of a Synthetically Fabricated Osteoinductive Biphasic Calcium Phosphate Bone Graft to BMP2 Improves New Bone Formation. Clin Implant Dent Relat Res. 2016 Dec;18(6): 1238-1247. [Medline: 26510170] [doi: 10.1111/cid.12384]

38. Fee L. Socket preservation. Br Dent J. 2017 Apr 21;222(8):579-582. [Medline: 28428609] [doi: $10.1038 /$ sj.bdj.2017.355]

39. Özveri Koyuncu B, Işık G, Özden Yüce M, Günbay S, Günbay T. Effect of concentrated growth factor (CGF) on short-term clinical outcomes after partially impacted mandibular third molar surgery: A split-mouth randomized clinical study. J Stomatol Oral Maxillofac Surg. 2019 Jul 9. pii: S2468-7855(19)30166-1. [Medline: 31299343] [doi: 10.1016/j.jormas.2019.07.002]

40. Anitua E, Murias-Freijo A, Alkhraisat MH, Orive G. Clinical, radiographical, and histological outcomes of plasma rich in growth factors in extraction socket: a randomized controlled clinical trial. Clin Oral Investig. 2015 Apr;19(3):589-600. [Medline: 24998770] [doi: 10.1007/s00784-014-1278-2]

41. Mashimo T, Sato Y, Akita D, Toriumi T, Namaki S, Matsuzaki Y, Yonehara Y, Honda M. Bone marrow-derived mesenchymal stem cells enhance bone marrow regeneration in dental extraction sockets. J Oral Sci. 2019;61(2):284-293. [Medline: $\underline{31217377]}$ [doi: 10.2334/josnusd.18-0143]

42. Tan L, Zhang Y, Huang Y, Luo Y, Liu Y. Preservation of alveolar ridge after tooth extraction with hypoxiainducible factor-1 $\alpha$ protein in a dog model. Exp Ther Med. 2019 Apr;17(4):2913-2920. [Medline: 30936961] [PMC free article: 6434234] [doi: 10.3892/etm.2019.7301]

43. Cho IW, Park JC, Shin HS. A comparison of different compressive forces on graft materials during alveolar ridge preservation. J Periodontal Implant Sci. 2017 Feb;47(1):51-63. [Medline: 28261524] [PMC free article: 5332335] [doi: 10.5051/jpis.2017.47.1.51]

44. Higgins J, Altman D, Sterne J. Assessing risk of bias in included studies. In: Higgins J, Green S, editors. Cochrane Handb Syst Rev Interv version 510 (updated March 2011) [Internet]. The Cochrane Collaboration; 2011. [URL: http://handbook.cochrane.org]

45. Kim YJ, Lee JY, Kim JE, Park JC, Shin SW, Cho KS. Ridge preservation using demineralized bone matrix gel with recombinant human bone morphogenetic protein-2 after tooth extraction: a randomized controlled clinical trial. J Oral Maxillofac Surg. 2014 Jul;72(7):1281-90. [Medline: 24709512] [doi: 10.1016/j.joms.2014.01.022]

46. Coomes AM, Mealey BL, Huynh-Ba G, Barboza-Arguello C, Moore WS, Cochran DL. Buccal bone formation after flapless extraction: a randomized, controlled clinical trial comparing recombinant human bone morphogenetic protein 2/absorbable collagen carrier and collagen sponge alone. J Periodontol. 2014 Apr;85(4):525-35. [Medline: 23826643] [doi: 10.1902/jop.2013.130207]

47. Huh JB, Lee HJ, Jang JW, Kim MJ, Yun PY, Kim SH, Choi KH, Kim YK, Cho KS, Shin SW. Randomized clinical trial on the efficacy of Escherichia coli-derived rhBMP-2 with $\beta$-TCP/HA in extraction socket. J Adv Prosthodont. 2011 Sep;3(3):161-5. [Medline: 22053248] [PMC free article: 3204453] [doi: 10.4047/jap.2011.3.3.161]

48. Jain A, Singh M, Ganapathy KP, Ramola V, Passi D, Jain K. Evaluation of two socket healing procedures with and without mesenchymal stem cells: A comparative study. Natl J Maxillofac Surg. 2016 Jul-Dec;7(2):159-165. [Medline: 28356687] [PMC free article: 5357932] [doi: 10.4103/0975-5950.201366]

49. Saulacic N, Schaller B, Muñoz F, Fujioka-Kobayashi M, Kobayashi E, Lang NP, Miron RJ. Recombinant human BMP9 (RhBMP9) in comparison with rhBMP2 for ridge augmentation following tooth extraction: An experimental study in the Beagle dog. Clin Oral Implants Res. 2018 Oct;29(10):1050-1059. [Medline: 30281171] [doi: 10.1111/clr.13371]

50. Pelegrine AA, da Costa CE, Correa ME, Marques JF Jr. Clinical and histomorphometric evaluation of extraction sockets treated with an autologous bone marrow graft. Clin Oral Implants Res. 2010 May;21(5):535-42. [Medline: 20337664] [doi: 10.1111/j.1600-0501.2009.01891.x] 
51. Geurs N, Ntounis A, Vassilopoulos P, Van der Velden U, Loos BG, Reddy M. Using growth factors in human extraction sockets: a histologic and histomorphometric evaluation of short-term healing. Int J Oral Maxillofac Implants. 2014 MarApr;29(2):485-96. [Medline: 24683578] [doi: 10.11607/jomi.3408]

52. Wallace SC, Pikos MA, Prasad H. De novo bone regeneration in human extraction sites using recombinant human bone morphogenetic protein-2/ACS: a clinical, histomorphometric, densitometric, and 3-dimensional conebeam computerized tomographic scan evaluation. Implant Dent. 2014 Apr;23(2):132-7. [Medline: 24614876] [doi: 10.1097/ID.0000000000000035]

53. Mayer Y, Ginesin O, Khutaba A, Machtei EE, Zigdon Giladi H. Biocompatibility and osteoconductivity of PLCL coated and noncoated xenografts: An in vitro and preclinical trial. Clin Implant Dent Relat Res. 2018 Jun;20(3):294-299. [Medline: 29508553] [doi: 10.1111/cid.12596]

54. Heberer S, Wustlich A, Lage H, Nelson JJ, Nelson K. Osteogenic potential of mesenchymal cells embedded in the provisional matrix after a 6-week healing period in augmented and non-augmented extraction sockets: an immunohistochemical prospective pilot study in humans. Clin Oral Implants Res. 2012 Jan;23(1):19-27. [Medline: 21435013] [doi: 10.1111/j.1600-0501.2010.02148.x]

55. Kaigler D, Pagni G, Park CH, Braun TM, Holman LA, Yi E, Tarle SA, Bartel RL, Giannobile WV. Stem cell therapy for craniofacial bone regeneration: a randomized, controlled feasibility trial. Cell Transplant. 2013;22(5):767-77. [Medline: 22776413] [PMC free article: 4100608] [doi: 10.3727/096368912X652968]

56. Chen G, Deng C, Li YP. TGF- $\beta$ and BMP signaling in osteoblast differentiation and bone formation. Int J Biol Sci. 2012;8(2):272-88. [Medline: 22298955] [PMC free article: 3269610] [doi: 10.7150/ijbs.2929]

57. Giannobile WV, Finkelman RD, Lynch SE. Comparison of canine and non-human primate animal models for periodontal regenerative therapy: results following a single administration of PDGF/IGF-I. J Periodontol. 1994 Dec;65(12):1158-68. [Medline: 7877089] [doi: 10.1902/jop.1994.65.12.1158]

\section{To cite this article:}

Pranskunas M, Galindo-Moreno P, Padial-Molina M.

Extraction Socket Preservation Using Growth Factors and Stem Cells: a Systematic Review

J Oral Maxillofac Res 2019;10(3):e7

URL: http://www.ejomr.org/JOMR/archives/2019/3/e7/v10n3e7.pdf

doi: $10.5037 /$ jomr.2019.10307

Copyright $@$ Pranskunas M, Galindo-Moreno P, Padial-Molina M. Published in the JOURNALOF ORAL \& MAXILLOFACIAL RESEARCH (http://www.ejomr.org), 5 September 2019.

This is an open-access article, first published in the JOURNAL OF ORAL \& MAXILLOFACIAL RESEARCH, distributed under the terms of the Creative Commons Attribution-Noncommercial-No Derivative Works 3.0 Unported License, which permits unrestricted non-commercial use, distribution, and reproduction in any medium, provided the original work and is properly cited. The copyright, license information and link to the original publication on (http://www.ejomr.org) must be included. 